\title{
PIK3CA wt Allele
}

National Cancer Institute

\section{Source}

National Cancer Institute. PIK3CA wt Allele. NCI Thesaurus. Code C51160.

Human PIK3CA wild-type allele is located in the vicinity of 3q26.3 and is approximately 36 $\mathrm{kb}$ in leng th. This allele, which encodes phosphatidylinositol-4,5-bisphosphate 3-kinase catalytic subunit alpha isoform protein, plays a role in signaling pathways underlying the regulation of apoptosis, cell growth, and angiogenesis. Somatic mutations in the PIK3CA gene that increase the enzymatic activity of its protein product are associated with a number of cancer types such as breast, colorectal and ovarian cancers. 